\title{
PEIMBELAJARAN SEJARAH KEBUDAYAAN ISLAMI BERBASIS GENDER DI MADRASAH ALIYAH KABUPATEN KEPULAUAN SELAYAR
}

\author{
Muhammad Rusmin B. \\ UIN Alauddin Makassar
}

\begin{abstract}
Penelitian tentang pelaksanaan pembelajaran Sejarah Kebudayaan Islam berbasis gender di Madrasah Aliyah Kabupaten Kepulauan Selayar adalah proses pembelajaran menggunakan kurikulum 2013. Guru mengajar menggunakan metode yang bervariasi, seperti metode ceramah, tanya jawab, dan yang lainnya. Faktor yang mendukung dalam proses belajar SKI berbasis gender yaitu diantaranya guru menggunakan metode yang bervariasi ketika mengajar, sehingga suasana kelas menjadi hidup dan peserta didik sangat bersemangat. Faktor penghambat pembelajaran sejarah kebudayaan Islam berbasis gender yaitu peserta didik belum mengetahui makna gender yang sesungguhnya. Upaya guru dalam mengatasi kesulitan belajar belajar SKI berbasis gender yang dialami oleh peserta didik yaitu guru mengarahkan lebih awal untuk mencari materi di google yakni materi tentang gender sehingga peserta didik lebih mudah memahami apa yang diajarkan. Selain itu, buku paket yang sudah tersedia diwajibkan bagi peserta didik untuk membaca lebih awal.
\end{abstract}

Keywords: Pembelajaran, Sejarah Kebudayaan Islam, Berbasis, Gender

\section{PENDAHULUAN}

\section{A. Latar Belakang Masalah}

Pendidikan merupakan hal yang sangat penting untuk menjamin perkembangan dan kelangsungan kehidupan bangsa. Pendidikan adalah usaha sadar untuk menyiapkan peserta didik melalui kegiatan bimbingan, pengajaran, dan/atau latihan bagi peranannya di masa yang akan datang. Setiap warga negara Indonesia berhak memperoleh pendidikan pada tahap manapun dalam perjalanan hidupnya. Pendidikan dapat diperoleh, baik melalui jalur pendidikan sekolah maupun jalur pendidikan luar sekolah. Peningkatan dan pemerataan pendidikan merupakan salah satu aspek pembangunan yang mendapat 
prioritas utama dari pemerintah Indonesia. Sistem Pendidikan Nasional yang sekarang berlaku diatur melalui undang-undang pendidikan nasional. ${ }^{1}$

Undang-Undang Republik Indonesia Nomor: 20 Tahun 2003 tentang Sistem

Pendidikan Nasional, Bab II Pasal 3 menjelaskan bahwa:

Pendidikan nasional berfungsi mengembangkan kemampuan dan membentuk watak serta peradaban bangsa yang bermartabat dalam rangka mencerdaskan kehidupan bangsa, bertujuan untuk berkembangnya potensi peserta didik agar menjadi manusia yang beriman dan bertakwa kepada Tuhan Yang Maha Esa, berakhlak mulia, sehat, berilmu, cakap, kreatif, mandiri, dan menjadi warga negara yang demokratis serta bertanggung jawab. ${ }^{2}$

Untuk mewujudkan fungsi dan tujuan pendidikan nasional tersebut, dalam tatanan mikro pendidikan diharapkan mampu menghasilkan SDM berkualitas dan profesional, termasuk kebutuhan dunia kerja dan respon terhadap perubahan masyarakat setempat. Salah satu faktor yang sangat berperan dalam mewujudkan fungsi dan tujuan pendidikan nasional adalah pendidik itu sendiri. Dalam Undang-Undang Republik Indonesia Nomor: 20 Tahun 2003 tentang Sistem Pendidikan Nasional pada Bab XI Pasal 39 ayat 2 disebutkan bahwa:

Pendidik merupakan tenaga profesional yang bertugas merencanakan dan melaksanakan proses pembelajaran, menilai hasil pembelajaran, melakukan pembimbingan dan pelatihan, serta melakukan penelitian dan pengabdian kepada masyarakat... ${ }^{3}$

Berdasarkan undang-undang tersebut, dapat dipahami bahwa guru merupakan salah satu komponen paling menentukan dalam sistem pendidikan secara keseluruhan yang harus mendapat perhatian sentral, pertama, dan utama. Figur yang satu ini akan senantiasa menjadi sorotan strategis ketika berbicara masalah pendidikan karena guru selalu terkait dengan komponen manapun dalam sistem pendidikan. Guru memegang peran utama dalam pembangunan pendidikan, khususnya yang diselenggarakan secara formal di sekolah/madrasah. Guru juga sangat menentukan keberhasilan peserta didik, terutama dalam kaitannya dengan proses pembelajaran. Bahkan guru merupakan komponen yang paling berpengaruh terhadap terciptanya proses dan hasil pendidikan yang berkualitas. Upaya perbaikan apapun yang dilakukan untuk meningkatkan kualitas pendidikan tidak akan memberikan sumbangan yang signifikan tanpa didukung oleh guru yang profesional dan berkualitas.

\footnotetext{
${ }^{1}$ Lihat, Dharma Pendidikan, "Profesionalisme Guru dan Paradigma Baru". http://www.blogspot.com/ 20110301/html (13 Januari 2020).

${ }^{2}$ Republik Indonesia, Undang-undang Republik Indonesia Nomor: 20 Tahun 2003 Tentang Sistem Pendidikan Nasional (Cet. IV; Jakarta: Sinar Grafika, 2007), h. 5-6.

${ }^{3}$ Republik Indonesia, Undang-undang Republik Indonesia Nomor: 20 Tahun 2003 Tentang Sistem Pendidikan Nasional, h. 20.
} 
Dinamika yang terjadi di Madrasah Aliyah Kabupaten Kepulauan Selayar memperlihatkan suasana harmonis dimana dalam komunitas tertentu sangat terlihat keterpaduan dan kerjasama atara peserta didik laki-laki dan perempuan. Hal ini juga dapat dilihat dari diskusi bersama dalam kelompok-kelompok kecil, aktif bersama dalam organisasi kesiswaan di semua level, dan membangun kreasi literasi secara bersamasama.

Berdasarkan deskripsi di atas, maka peneliti memandang perlu untuk mengkaji lebih mendalam dengan melakukan penelitian yang berjudul: "Pembelajaran Sejarah Kebudayaan Islam Berbasis Gender di Madrasah Aliyah Kabupaten Kepulauan Selayar"

\section{B. Rumusan Masalah}

Berdasarkan latar belakang yang telah dikemukakan oleh penulis, maka rumusan masalah yang akan dibahas adalah sebagai berikut:

1. Bagaimana bentuk pembelajaran sejarah kebudayaan Islam berbasis gender di Madrasah Aliyah Kabupaten Kepulauan Selayar?

2. Bagaimana pendukung dan penghambat pembelajaran sejarah kebudayaan Islam berbasis gender di Madrasah Aliyah Kabupaten Kepulauan Selayar?

3. Bagaimana solusi kesulitan belajar sejarah kebudayaan Islam berbasis gender di Madrasah Aliyah Kabupaten Kepulauan Selayar?

\section{B. METODE PENELITIAN}

\section{A. Jenis dan Lokasi Penelitian}

\section{Jenis penelitian}

Penelitian ini adalah penelitian kualitatif bersifat deskriptif yang merupakan suatu bentuk penelitian ditujukan untuk mendeskripsikan fenomena-fenomena yang ada, baik fenomena alamiah maupun fenomena buatan manusia. Fenomena itu bisa berupa bentuk, aktivitas, karakteristik, perubahan, hubungan, kesamaan, dan perbedaan antara fenomena yang satu dengan fenomena lainnya. ${ }^{4}$ Penelitian kualitatif diskritif adalah suatu penelitian yang datanya diperoleh melalui obsevasi, wawancara dan dokumentasi. ${ }^{5}$

\footnotetext{
${ }^{4}$ Sukmadinata, Metode Penelitian Pendidikan (Cet. I; Bandung: Rosdakarya, 2006), h. 72.

${ }^{5}$ Mukhtar, Metode Praktis Penelitian Deskriptif Kualitatif (Jakarta: Referensi, 2013), h. 25.
} 
2. Lokasi penelitian

Adapun lokasi penelitian ini di Madrasah Aliyah Kabupaten Kepulauan Selayar.

\section{B. Metode Pengumpulan Data}

Teknik yang digunakan dalam mengumpulkan data-data penelitian ini adalah sebagai berikut:

\section{Observasi}

Observasi adalah cara yang digunakan jika ingin peneliti mendapat motivasi sikap dan harapan. Juga kejadian yang sudah berlaku, hal-hal yang belum terjadi dan kelakuan yang amat pribadi.

Observasi adalah salah satu alat bantu untuk memahami lebih dekat sasaran yang diteliti dengan melakukan pengamatan terhadap objek yang diteliti. Pengamatan difokuskan pada kegiatan yang dilakukan oleh peserta didik di Madrasah Aliyah Kabupaten Kepulauan Selayar.

2. Wawancara

Wawancara adalah percakapan dengan maksud tertentu. Percakapan dilakukan oleh dua orang. Wawancara adalah merekonstruksi mengenai orang-orang, kejadian organisasi, perasaan, motivasi, tuntutan, kepedulian, proyeksi, memferivikasi, mengubah, dan memperluas informasi yang diperoleh.

Dalam wawancara, berlangsung interaktif antara pewawancara dengan informan dalam rangka menelusuri data-data yang akurat dan faktual. Untuk memudahkan dan struktur informasi, peneliti menyiapkan sistematika bahan dan istrumen wawancara yang ada hubungannnya dengan penelitian. Selain itu ditentukan calon informan yang diyakini memiliki pengetahuan yang ada relavansinya dengan data penelitian.

\section{Dokumentasi}

Dokumentasi adalah mencari data-data berupa catatan, transkrip, buku, surat kabar, majalah, prasasti, notulen rapat, lengger, dan sebagainya. Dokumentasi adalah salah instrumen dalam pengumpulan data. Dokumen diperlukan untuk keaslian dan keakuratan data yang diperlukan. Dokumentasi dapat memberikan informasi terutama yang berhubungan kegiatan yang dilakukan oleh peserta didik di Madrasah Aliyah Kabupaten Kepulauan Selayar.

\section{Teknik Pengumpulan dan Analisis Data}

Data-data yang terkumpul kemudian diolah dengan menggunakan teknik deskriptif kualitatif. Teknik analisis deskriptif kualitatif yang dimaksud dalam penelitian ini adalah analitik non statistik dengan pendekatan induktif yaitu suatu analisis data yang bertolak dari problem atau pernyataan maupun tema spesifik yang dijadikan fokus penelitian. Jika dikaitkan dengan penelitian ini, maka pembelajaran demokratis yang dilaksanakan oleh 
guru di dalam kelas, akan diamati lalu hasil pengamatan tersebut akan digambarkan sebagaimana adanya, baik berupa gagasan pemikiran dan derivasinya, melalui pernyataan sumber data dan tema penelitian itu sendiri dalam hubungannya dengan kegiatan pembelajaran yang berorientasi pembelajaran demokratis.

Penulis menggunakan tiga cara dalam mengolah data penelitian yaitu:

\section{Reduksi data}

Reduksi data adalah proses memilih, menyederhanakan, memfokuskan, mengabstraksi, dan mengubah data kasar yang muncul dari catatan-catatan lapangan. Reduksi data dimaksudkan untuk menentukan data ulang sesuai dengan permasalahan penelitian.

2. Sajian data atau display data

Sajian data atau display data adalah suatu cara merangkai data dalam suatu organisasi yang memudahkan untuk membuat kesimpulan atau tindakan yang diusulkan. Sajian data pada peneltian ini adalah memilih data yang disesuaikan dengan kebutuhan penelitian.

\section{Verifikasi data}

Verifikasi data adalah penjelasan tentang makna data dalam suatu konfigurasi yang secara jelas menunjukkan alur kausalnya, sehingga dapat diajukan proposisi yang terkait dengannya. Verifikasi data penelitian ini dipakai untuk penentuan hasil akhir dari keseluruhan proses tahapan analisis, sehingga keseluruhan permasalahan dapat dijawab sesuai dengan kategori data dan masalahnya. Pada bagian ini akan muncul kesimpulankesimpulan yang komprehensif dan mendalam dari data hasil penelitian.

\section{KAJIAN TEORI}

\section{A. Sejarah Kebudayaan Islam}

\section{Pengertian Sejarah Kebudayaan Islam}

Istilah sejarah (history) diambil dari kata historia dalam bahasa Yunani berarti informasi atau penelitian yang ditujukan untuk memperoleh kebenaran. Sejarah pada masa lalu hanya berisi tentang "manusia-kisahnya" kisah tentang usaha-usahanya dalam memenuhi kebutuhan untuk menciptakan kehidupan yang tertib dan teratur, kecintaan akan kemerdekaan serta kehausannya akan keindahan dan pengetahuan. ${ }^{6}$

Sejarah Kebudayaan Islam di Madrasah Aliyah merupakan salah satu mata pelajaran yang menelaah tentang asal-usul perkembangan, peranan kebudayaan/peradaban Islam dan para tokoh yang berprestasi. Sejarah Islam dimasa lampau mulai dari perkembangan masyarakat Islam pada masa Nabi Muhammad saw,

${ }^{6}$ S K. Kochhar, Pembelajaran Sejarah Teaching Of History (Jakarta: Grasindo, 2008), h. 1. 
Khulafaur-rasyidin, Bani Umayyah, Bani Abbasiyah, Bani Ayyubiyah sampai perkembangan Islam di Indonesia.

\section{Tujuan Sejarah Kebudayaan Islam}

Pembelajaran sejarah kebudayaan Islam setidaknya memiliki beberapa tujuan antara lain sebagai berikut:

1) Peserta didik yang membaca sejarah adalah untuk menyerap unsur-unsur keutamaan agar mereka dengan senang hati mengikuti tingkah laku para Nabi dan orang-orang saleh dalam kehidupan sehari-hari.

2) Pelajaran sejarah merupakan contoh teladan baik bagi umat Islam yang meyakininya dan merupakan sumber syariah yang besar.

3) Pelajaran sejarah Islam dapat mengembangkan iman, mensucikan moral, membangkitkan patriotisme dan mendorong untuk berpegang pada kebenaran.

4) Pembelajaran sejarah akan memberikan contoh teladan yang sempurna kepada pembinaan tingkah laku manusia yang ideal dalam kehidupan.

5) Untuk pendidikan akhlak, selain mengetahui perkembangan agama Islam seluruh dunia. $^{7}$

Dapat disimpulkan bahwa dengan mempelajari Sejarah Kebudayaan Islam, kita mendapatkan informasi mengenai kebudayaan dan kekayaan serta keahlian di bidangbidang tertentu yang pernah diraih oleh umat Islam pada masa terdahulu, sehingga peserta didik memperoleh pengetahuan yang memadai tentang masa lalu Islam dan kebudayaannya.

\section{B. Gender}

\section{Pengertian Gender}

Menurut Kamus Besar Bahasa Indonesia, kata gender berarti jenis kelamin atau halhal yang berhubungan dengan jenis kelamin. ${ }^{8}$ Hal tersebut menggambarkan secara genetika memiliki perbedaan substantif baik dari segi struktur biologis maupun suasana kejiwaan. Ada hal-hal tertentu yang secara biologis dimiliki dan dapat dilakukan oleh perempuan tetapi tidak bisa dilakukan oleh laki-laki. Hal tersebut bisa terjadi karena struktur biologis perempuan yang memang diciptakan oleh Allah seperti itu sehingga

${ }^{7}$ S K. Kochhar, Pembelajaran Sejarah Teaching of History, h. 5.

${ }^{8}$ Dewi, Ernita. “Kesetaraan Gender dalam Islam: Sudut Pandang Al- Qur'an dan Hadis (Ernita Dewi: 2014), h. 269-280. 
tidak dapat dilakukan oleh laki-laki, misalnya suara perempuan lebih lengking dibandingkan dengan laki-laki.

Kata gender berasal dari bahasa Inggris, gender, berarti jenis kelamin. ${ }^{9}$ Dalam Webster's New World Dictionary, gender diartikan sebagai "perbedaan yang tampak antara laki-laki dan perempuan dilihat dari segi nilai dan tingkah laku". ${ }^{10}$ Dalam Women's Studies Encyclopedia dijelasakan bahwa gender adalah suatu konsep kultural yang serupa membuat perbedaan (Distinction) dalam hal peran, perilaku, mentalitas, dan karakteristik emosional antara laki-laki dan perempauan yang berkembang dalam masyarakat. ${ }^{11}$ Hilary M. Lips dalam bukunya yang terkenal Sex \& Gender: An Introduction mengartikan gender sebagai harapan-harapan budaya terhadap laki-laki dan perempuan (Culture exspectation for women and man). ${ }^{12}$ Misalnya sejalan dengan apa yang dikatakan Mansour Fakih bahwa perempuan dikenal dengan lemah lembut, cantik, emosional, dan keibuan. Sementara laki-laki dianggap kuat, rasional, jantan, dan perkasa. ${ }^{13}$ Ciri-ciri dari sifat itu merupakan sifat yang dapat dipertukarkan, misalnya ada laki-laki yang lemah lembut, ada perempuan yang kuat, rasional, dan perkasa. Perubahan ciri dan sifat itu dapat terjadi dari waktu ke waktu dan dari tempat ke tempat lain. ${ }^{14}$ Baidowi mengutip pendapat Ann Oskley, yang berpendapat bahwa gender adalah sifat dari laki-laki dan perempuan yang dikonstruksi secara sosial dan kultural, sehingga tidak identik dengan seks. ${ }^{15}$

\section{Perbedaan Gender dan Seks (Jenis Kelamin)}

Konsep penting yang perlu dipahami dalam rangka membahas masalah kaum perempuan adalah membedakan antara konsep seks dan konsep gender. Sesungguhnya gender dan seks itu berbeda, gender digunakan untuk mengidentifikasi perbedaan lakilaki dan perempuan dari aspek sosial budaya. Sedangkan perbedaan seks digunakan untuk mengidentifikasi perbedaan laki-laki dan perempuan secara anatomis dan biologis. Aan

${ }^{9}$ Jhon M. Echols dan Hasan Shadily, Kamus Inggris Indonesia, (Cet. XII; Jakarta: Gramedia, 1983), h. 265.

${ }^{10}$ Victoria Neufealdt (ed), Webster's New World Dictionary (New York: Webstere ${ }^{\text {ee }}$ New World Clevenland, 1984), h. 561.

${ }^{11}$ Helen Tierney (ed), Women Studies Encyclopedia (New York: Green Wood Press, tt), h. 153.

${ }^{12}$ Hilary M. Lips, Sex \& Gender; An Introduction (Californnia: MyField Publishing Company, 1993), h. 4. Lihat juga Amiruddin Arani dan Faqihuddin Abdul Qadir (ed), dalam Bunga Rampai Tubuh, Seksualitas dan Kedaluatan Perempuan (Yogyakarta: LKis, 2002), h.197.

${ }^{13}$ Mansour Fakih, Analisis Gender dan Transformasi Sosial (Yogyakarta: Pustaka Pelajar, 1999), h. 8 .

${ }^{14}$ Priyo Soemandoyo, Wacana Gender \& Layar Televisi: Studi Perempuan Dalam Pemberitaan Televisi Swasta (Yogyakrta: LP3Y,1999), h. 58-59. Lihat juga dalam buku Mufida, Ch, Paradigma Gender (Malang: Bayu Media Publishing, 2004), h. 4.

${ }^{15}$ Ahmad Baidawi, Gerakan Feminisme Dalam Islam, Jurnal Penelitian Agama (Yogyakarta: Pusat Penelitian UIN Yogyakarta, 2001, h. 203. 
Oskley seorang ahli sosiologi Inggris adalah orang pertama yang memberikan perbedaan istilah seks dan gender. Semua tokoh feminim sepakat dalam memberikan defenisi tentang seks, yakni perbedaan seks adalah perbedaan atas dasar ciri-ciri biologis dari lakilaki dan perempuan, terutama yang menyangkut pro-kreasi dan merupakan kodrat. ${ }^{16}$ Gender digunakan untuk mengidentifikasi perbedaan pria dan wanita dari aspek sosial budaya.

Studi gender lebih menekankan pada perkembangan aspek maskulinitas dan feminis seseorang, sedangkan seks lebih menekankan pada perkembangan aspek biologis dan komposisi kimia dalam tubuh laki-laki dan perempuan. Musdah Mulia dalam bukunya Muslimah Reformis, mengatakan jenis kelamin laki-laki ditandai dengan adanya penis, testis, dan sperma, sedangkan perempuan mempunyai vagina, payudara, ovum, dan rahim. Perbedaan tersebut bersifat kodrati, atau pemberian Tuhan. ${ }^{17}$ Karena sifatnya yang bukan kodrati dan dibentuk secara sosial, maka ia dapat berubah dari waktu ke waktu, dan dapat berbeda bentuk pada tempat yang berbeda. Maskulinitas dan feminitas pun sesungguhnya bukan sesuatu yang kodrati, namun merupakan hasil kontsruksi sosial. Buktinya, dalam realitas sosiologi di masyarakat ditemukan tidak sedikit laki-laki penakut, emosional, pemalu, lemah, dan lembut. Sebaliknya, cukup banyak perempuan yang kuat, berani, perkasa, pantang menyerah, rasional, dan sangat tegar.

\section{Issu-issu Gender dalam Pemerintahan Khulafaur Rasyidin}

a. Pemerintahan Abu Bakar Ash-Shiddiq

1) Asma Binti Abu Bakar

Asma binti Abu Bakar nasabnya adalah Asma binti Abdullah bin Abi Quhafah Uthman bin Amir bin Amr bin Ka'ab bin Sa'id bin Taim bin Murrah bin Ka'ab bin Lu'ay. Ayahnya adalah Abu Bakar Ash-Șhiddiq dan ibunya adalah Qutailah binti Abdul 'Uzza bin 'Abdu al-As'ad bin Nașr bin Malik bin Hasl bin 'Amir bin Lu'ay. Asma' adalah saudari Abdullah bin Abu Bakar dari pihak ayah dan ibu. Dia diperistri oleh Zubair bin Awwam dan memiliki putra Abdullah bin Zubair, 'Urwah bin Zubair, Mundir bin Zubair, Muhajir bin Zubair dan 'Ashim bin Zubair. Asma' binti Abu Bakar adalah saudari Aisyah Ra, istri Rasulullah saw dari pihak ayah.

Asma lahir di Mekkah ketika ayahnya berusia dua puluh tahun lebih, usia Asma 17 tahun lebih tua dari pada Aisyah, saudarinya.18 Asma hidup layaknya seperti anak-anak yang lain di tengah keluarga dengan profesi orang tua sebagai pedagang pakaian.

${ }^{16}$ Ratna Saptari, Perempuan Kerja dan Perubahan Sosial Sebuah Pengantar Studi Perempuan (Jakarta: Kalyana Mitra, 1997), h. 89.

${ }^{17}$ Siti Musdah Mulia, Muslimah Sejati; Menempuh Jalan Islami Meraih Ridha Ilahi (Bandung: Marja, 2011), h. 65.

${ }^{18}$ Muhammad Husain Haekal, Abu Bakar Ash Siddiq, h. 3. 
Asma dalam riwayat hidupnya tergolong sebagai orang yang awal masuk Islam. Asma masuk Islam setelah 16 orang pertama masuk Islam, yaitu Khadijah Ra, Ali bin Abi Țhālib , Zaid bin Haritsah, Abu Bakar Ra, Utsman bin Affan, Zubair bin Awwam, Abdurrahman bin Auf, Sa'ad bin Abi Waqqash, Țalhah bin Ubaidillah, Abu Ubaidah, Abu Salamah, Al-Arqam bin Abi al-Arqam, Utsman bin Madz'un, Ubaidah bin Al-Harits, Sa'id bin Zaid, dan Fāțimah binti Khațtab. Asma merupakan urutan ketujuh belas dalam golongan orang pertama yang masuk Islam. ${ }^{19}$

Jiwa juang yang dimilikinya menjadi bahagian yang tidak terpisahkan dari perjuangan agama sesudahnya. Asma dikenal dalam sejarah adalah seorang tabib, dan perawi hadis. ${ }^{20}$ Sebagai tabib, Asma mampu menangkap isyarat-isyarat Nabi yang berhubungan dengan urusan medis dan penyembuhan. Suatu ketika Asma didatangi wanita yang demam dan minta tolong kepadanya, maka ia mengambil air dan menuangkannya ke antara badan dan sela bajunya. Asma berkata: "Sesungguhnya Rasulullah saw memerintahkan kami supaya mendinginkannya dengan air". Beliau bersabda: "Dinginkanlah dengan air, sesungguhnya panas itu adalah sebagian dari air mendidih di Neraka Jahannam".

2) Ummu Imarah

Masa pemerintahan Abu Bakar terdapat konflik yang serius yaitu menghadapi nabi palsu Musailamah al Kadzab. Musailamah adalah pemimpin Bani Hanifah di Yamamah, wilayah yang terletak di Saudi Timur. Gelar al-Kadzab diberikan oleh Rasulullah karena dia adalah seorang pendusta besar.

Semakin lama, Musailamah semakin kuat untuk menghadapi pasukan Islam. Peperangan telah dipersiapkan dengan baik, tentara Yamamah sebanyak 40.000 orang di bawah komando Musailamah al Kadzab. Sedangkan pasukan muslim di bawah komando Khalid bin Walid. Peristiwa ini tercatat sebagai pertempuran terbesar umat muslim melawan gerakan murtad, pertempuran pun berlangsung sengit. ${ }^{21}$

Sengitnya perlawanan kaum muslimin terhadap pasukan Yamamah di bawah komando Musailamah tergolong luar biasa karena terdapat pasukan muslimah yaitu Ummu Imarah. Dia turut mengangkat senjata bersama laki-laki melawan pasukan Yamamah. Peperangan tersebut dimenangkan oleh pasukan muslim. Hal ini berarti wibawa Islam sebagai suatu kekuatan sangat diperhitungkan dengan kelompok dan negara-negara lain.

\footnotetext{
${ }^{19}$ Abu Muhammad Abdul Malik bin Hishām, Sīrah al-Nabawiyah Ibnu Hishām, Terj. Fadhli Bahri (Jakarta: Darul Falah, 2000), 214-215.

${ }^{20} \mathrm{Abu}$ Ja'far Muhammad bin Jarir al-Ṭabari, Tarikh al-Ṭabari: Tārikh al- Umam wa al-Muluk, (Mesir: Dar al-Ma'arif, 1996), h. 586.

${ }^{21}$ http://jakaadhitea.blogspot.com/2017/09/musailamah-al-kadzab-sang-nabi-palsu.html
} 
Keterlibatan perempuan dalam perang Yamamah menunjukan bahwa apa yang dimiliki laki-laki juga dimiliki perempuan. Perempuan memiliki keberanian mengahadapi musuh dan tidak gentar sedikit pun dan akan terus ia maju sampai mencapai kemenangan. Perempuan juga memiliki taktik dan strategi perang yang tidak kurang dari apa yang dimiliki laki-laki. Bagi perempuan yang ikut berperang, memiliki konsekwensi yang tidak dimiliki laki-laki. Tugas dan keibuan perempuan akan ditanggalkan dan dipindahkan kepada orang lain dalam mengasuh dan menangani anak-anaknya.

b. Pemerintahan Umar bin Khattab

1) Asy Syifa' binti Abdillah Al Adawiyah.

Rasulullah pernah mengangkat seorang wanita bernama Samra' binti Nahika Al Asadiyah sebagai pengawas pasar (Al Hasabah) di Makkah. Pengawas pasar adalah salah satu jabatan publik di bawah departemen keamanan. Pada masa pemerintahan Umar bin Khattab, Samra' binti Nahika Al Asadiyah dibekali sehelai cambuk untuk mencambuk para pedagang yang tidak tertib. Umar bin Al Khattab juga mengangkat seorang pengawas wanita bernama Asy Syifa' binti Abdillah Al Adawiyah untuk mengawasi pasar di Madinah. ${ }^{22}$

2) Hafshah

Pada masa pemerintahan Abu Bakar dan berlanjut pada masa Umar bin Khattab, dilakukan pengumpulan al Qur'an. Hafshah berperan dalam kodifikasi Al-Quran, Profesor Ruqayya Khan, ketua Islamic Studies di Claremont Graduate University, California merilis sebuah penelitian yang ia beri judul: "Did a Woman Edit the Quran? Hafsa's Famed Codex." Khan mengklaim bahwa Hafshah telah mentranskrip, dan kemudian menyebarkan ayat-ayat Al-Quran. ${ }^{23}$ Menurutnya, ini sangat menarik di tengah gelombang pendiskreditan perempuan. Pada kenyataannya, Hafshahlah satu-satunya istri Nabi yang memiliki kecerdasan intelektual melebihi istri-istri yang lain. Dia berpikir, berdebat, dan selalu mengajukan pertanyaan. ${ }^{24}$ Dari semua istrinya, ia mungkin satusatunya yang dapat membaca dan menulis. Beberapa dari mereka mungkin mengerti cara pelafalan sesuatu, tetapi mereka tidak mengetahui cara menulisnya.

\section{$\underline{5 \mathrm{YCrr} 4 \mathrm{Kgn}}$}

${ }^{22}$ https://www.syahida.com/2014/11/24/784/wanita-menduduki-jabatan-publik/_ \#axzz

${ }^{23}$ https://ganaislamika.com/al-quran-dan-perempuan-1-peran-hafshah-dalam-kodifikasi-al-quran/

24“Woman Help Write Quran” dalam https://www.vocativ.com/culture/religion/woman-helpwrite-quran/index.html 


\section{HASIL PENELITIAN DAN PEMBAHASAN PEMBELAJARAN SEJARAH KEBUDAYAAN ISLAM BERBASIS GENDER DI MADRASAH ALIYAH KABUPATEN KEPULAUAN SELAYAR}

\section{A. Gambaran Umum Lokasi Penelitian}

\section{Letak Geografis MAN Kepulauan Selayar}

MAN Kepulauan Selayar terletak di Jl. H. Aeroppala No. 46 kecamatan Benteng, Kelurahan Benteng Selatan, Kota Benteng, Kabupaten Kepulauan Selayar, Provinsi Sulawesi Selatan. MAN Kepulauan Selayar dengan luas tanah kurang lebih $1,320 \mathrm{~m}^{2}{ }^{25}$

\section{Sejarah Berdirinya MAN Kepulauan Selayar}

Madrasah Aliyah Negeri Kepulauan Selayar pada awalnya berasal dari salah satu Lembaga Pendidikan Kejuruan yaitu Pendidikan Guru Agama (PGA) 6 tahun, yang didirikan pada tahun 1968, tepatnya pada tanggal 1 Januari 1968 yang diprakarsai oleh tokoh masyarakat dan tokoh agama yaitu:

a) K.H. Abdul Kadir Kasim (Tokoh Pendidik)

b) K.H. Abd. Gani Saleh (Tokoh Masyarakat)

c) Burhanuddin Idris (Tokoh Pendidik)

d) Abdullah Bahari (Tokoh Masyarakat)

e) H. Syahrir Thahir (Tokoh Masyarakat)

Dasar pemikiran pendirian institusi pada saat itu adalah adanya tuntutan kebutuhan masyarakat Selayar yang menginginkan adanya lembaga pendidikan yang berbasis agama (basic religion). Lembaga ini diharapkan dapat menjadi pusat pembinaan ruh keagamaan dan praktik keagamaan, mampu memproduksi mubaligh dan mubalighah yang mampu melakukan syiar dalam memberikan pencerahan agama kepada masyarakat Selayar dan menjadi pusat kajian keagamaan yang dapat mewarnai sikap dan perilaku religius masyarakat Selayar.

Dengan melihat dasar pemikiran berdirinya MAN Kepulauan Selayar terlihat bahwa MAN Kepulauan Selayar adalah lembaga pendidikan yang diselenggarakan dengan konsep pendidikan berbasis masyarakat (community based education) yakni pendidikan yang diselenggarakan berdasarkan kekhasan agama Islam serta sosial, budaya aspirasi, dan potensi masyarakat Islam Selayar sebagai perwujudan pendidikan dari, oleh, dan untuk masyarakat. Dasar pemikiran ini mendapat dukungan dari Kepala Kantor Inspeksi Pendidikan Agama Daerah Tk. II Selayar (saat itu) yang sekarang disebut Seksi Pendidikan Agama Islam pada Kantor Departemen Agama Kabupaten Selayar.

\footnotetext{
${ }^{25}$ Dokumentasi MAN Kepulauan Selayar, Ruang Tata Usaha, Senin, 10 Februari $2020 .$.
} 


\section{B. Bentuk Pembelajaran Sejarah Kebudayaan Islam Berbasis Gender di Madrasah}

\section{Aliyah Kabupaten Kepulauan Selayar}

Pelaksanaan pembelajaran SKI berbasis gender di Madrasah Aliyah Kabupaten Kepulauan Selayar menggunakan kurikulum 2013. Guru mengajar menggunakan metode yang bervariasi, seperti metode ceramah, tanya jawab, dan yang lainnya. Seluruh peserta didik kelas XI yang terbagi dalam 4 kelas, diampu oleh guru SKI bernama Nur Aida. Adapun proses kegiatan pembelajaran SKI berbasisi gender yang dilakukan guru SKI tergambarkan sebagai berikut:

Senin 10 Februari 2020, guru SKI memasuki ruang kelas pada pukul 07.25 WITA untuk melakukan kegiatan pembelajaran SKI. Tidak berlama-lama, guru segera membuka pelajaran dengan salam, doa, dan mempresensi kehadiran peserta didik. Setelah itu, guru segera mulai mereview sedikit tentang materi yang telah diajarkan sebelumnya. Kini tiba saatnya pada materi selanjutnya yaitu tentang gender.

Dalam menerangkan kepada peserta didik, guru menggunakan metode membaca. Pada saat guru membacakan materi, peserta didik menyimak dalam buku paket mereka. Sesekali, guru menuliskan poin penting di papan tulis depan kelas. Sembari mengajak peserta didik aktif, ketika menulis guru mencoba menanyakan poin yang dicatat itu pada peserta didik. Kemudian beramai-ramai peserta didik menjawab poin-poin tersebut.

Usai menuliskan poin penting di depan kelas, guru melanjutkan membacakan materi, dan peserta didik menyimak. Begitu seterusnya hingga materi usai. Di sela-sela guru menyampaikan materi, dengan sigap peserta didik mencatat hal-hal penting yang telah disampaikan oleh guru dalam buku catatan mereka.

Ketika materi selesai disampaikan, guru menginstruksikan kepada peserta didik agar menutup buku paket dan catatan mereka. Guru juga menghapus catatan di papan tulis. Selanjutnya secara spontan guru memanggil nama salah satu peserta didik, dan memberinya soal untuk dijawab seketika. Peserta didik pertama mampu menjawab pertanyaan dengan mudah. Kembali guru memanggil peserta didik kedua dan ketiga secara bergantian. Dari 3 peserta didik yang diberikan pertanyaan tersebut, semuanya mampu menjawab soal tanpa berpikir lama. Belum merasa puas, guru menambah 3 lagi peserta didik. Ketika peserta didik tersebut diminta untuk menjelaskan materi yang telah disampaikan tadi, dengan benar mereka menjelaskan kepada guru tersebut. Tiba giliran peserta didik yang ketujuh, dia tidak mampu menjawab secara lugas alias terbata-bata. Demikian seterusnya sampai peserta didik yang kesepuluh.

Setelah guru merasa cukup menyampaikan materi, peserta didik diminta untuk mengerjakan tugas uji kompetensi yang ada dalam Lembar Kerja Peserta Didik (LKPD). Beberapa peserta didik aktif dengan cepat menemukan jawaban dari tugas-tugas tersebut. Namun masih banyak peserta didik yang bingung mencari jawabannya dengan membolak-balik lembar LKPD. Beberapa menit peserta didik mengerjakan tugas, bunyi 
bel tanda pembelajaran berakhir terdengar. Selanjutnya guru segera menutup pembelajaran dengan salam penutup. ${ }^{26}$

\section{Pendukung dan Penghambat Pembelajaran Sejarah Kebudayaan Islam Berbasis Gender di Madrasah Aliyah Kabupaten Kepulauan Selayar}

Dalam proses pembelajaran yang telah diobservasi dan dialami oleh peserta didik Kelas XI IPA 1 ketika belajar SKI berbasis gender, tentunya ada yang mendukung dan menghambat atau mempengaruhi proses pembelajaran peserta didik.

Hasil pengamatan menunjukkan bahwa peserta didik sangat antusias terhadap proses kegiatan belajar di kelas. Hal ini seperti yang diungkapkan oleh Nur Aida, guru SKI berikut:

"Untuk pelaksanaan pembelajaran SKI itu pada dasarnya semua peserta didik antusias dalam mengikuti pelajaran karena materinya sangat menarik, terutama materi khulafurrasyidin. Kendalanya hanya pada materi gender karena mereka belum mengetahui sama sekali tentang gender". ${ }^{27}$

Senada dengan yang disampaikan oleh Nur Aida, peserta didik kelas XI juga memberikan pernyataan yang sama terkait pembelajaran SKI berbasis gender yang ada di kelas, sebagaimana yang penulis paparkan berikut:

"Pelaksanaan pembelajaran SKI di kelas XI selama ini berjalan baik, tenang, nyaman dan tidak membosankan. Kadang menegangkan, tetapi pelajaran mudah dipahami, berjalan lancar dan seru. Guru dan peserta didik dapat bekerja sama, semua perserta didik memperhatikan dan tidak ada yang gaduh. Metode yang dipakai guru sangat baik, membuat perserta didik ceria, serius dan menyenangkan, kondusif, sangat tidak membosankan dan jelas saat menyampaikan. Hanya saja ketika masuk materi gender, kami belum memahaminya", ${ }^{28}$

Salah seorang peserta didik ketika diwawancarai tentang materi gender, maka dia pun menjawab dengan hal yang serupa sebagai kutipan wawancara di bawah ini:

"Dalam pembelajaran di kelas, guru menggunakan metode yang bervariasi yakni membaca, mencatat, menghafal, ceramah, menulis, memberi soal latihan, post test, peserta didik menjelaskan kembali, dan penugasan. Dengan metode yang dipakai guru tersebut, kami merasa senang, nyaman, tetapi kadang deg-degan. Mengasikkan, memotivasi, membuat bersemangat dan kadang ada perasaan takut saat lupa materi. Tetapi ketika memasuki materi gender, kami merasa masih asing dengan istilah itu". 29

\footnotetext{
${ }^{26}$ Hasil observasi kelas pada hari Senin, 10 Februari 2020 pukul 07.55 WITA di ruang Kelas IPA 1.

${ }^{27}$ Hasil wawancara dengan guru SKI pada hari Senin, 10 Februari 2020 pukul 09.05 WITA di ruang kepala madrasah).

${ }^{28}$ Hasil wawancara dengan Ahmad Firdaus Ibrahim (Peserta Didik Kelas XI IPA 1) pada hari Senin, 10 Februari 2020 pukul 09.15 WITA di ruang kepala madrasah).

${ }^{29}$ Hasil wawancara dengan Rezki Eka Putri (Peserta Didik Kelas XI IPS 1) pada hari Senin, 10 Februari 2020 pukul 09.25 WITA di ruang kepala madrasah).
} 
Sebagaimana hasil wawancara dengan Nur Aida selaku guru mata pelajaran SKI, mengatakan:

"Faktor yang menyebabkan peserta didik mengalami kesulitan dalam belajar SKI berbasis gender adalah dikarenakan mereka sama sekali belum mengetahui secara mendalam makna gender yang sesungguhnya. Dalam materi pelajaran, ada pembahasan tentang gender, tetapi yang mereka tahu bahwa gender itu adalah jenis kelamin". ${ }^{30}$

Berdasarkan hasil wawancara di atas, maka dapat ditarik kesimpulan bahwa ada faktor yang mempengaruhi kesulitan belajar SKI berbasis gender yaitu peserta didik belum mengetahui makna gender yang sesungguhnya. Salah satu alasannya adalah, mereka kurang membaca referensi yang berkaitan dengan gender.

Berdasarkan hasil wawancara dengan saudara Muflih Zain selaku peserta didik yang mengalami kesulitan dalam belajar SKI berbasis gender, dia mengatakan:

"Kurangnya membaca referensi yang berkaitan dengan gender yang menyebabkan saya susah belajar SKI berbasis gender. Selain itu pula ketika membuka google, tidak pernah sekalipun membuka link yang berkaitan dengan gender". 31

Hal ini juga didukung oleh hasil wawancara dengan Husnawati selaku wakil kepala madrasah yang mengatakan:

"Iya, ini anak zaman sekarang memang kebanyakan bermain HP, tetapi lebih banyak main game atau membuka link yang tidak ada kaitannya dengan pembelajaran, sehingga ketika memasuki kelas untuk belajar materi yang akan dipelajari hari itu, mereka menjadi kelabakan". ${ }^{32}$

Hasil wawancara lain dengan peserta didik yang juga mengalami kesulitan dalam belajar SKI berbasis gender yang bernama Sarmila Dewi mengatakan:

"Saya memang sering membuka HP, tetapi lebih suka membaca komik atau cerpen ketimbang membaca materi yang akan diajarkan oleh guru pada pertemuan berikutnya". 33

Selain faktor yang mempengaruhi kesulitan peserta didik ketika belajar SKI berbasis gender, ada juga faktor pendukung dan faktor penghambat yang juga ikut mempengaruhi peserta didik dalam belajar SKI seperti ketergantungan kepada HP dan bermain game.

\footnotetext{
${ }^{30}$ Hasil wawancara dengan Nur Aida, S.Ag, Guru Mata Pelajaran SKI. pada hari Senin, 10 Februari 2020 pukul 09.35 WITA di ruang kepala madrasah).

${ }^{31}$ Hasil wawancara dengan Muflih Zain (Peserta Didik Kelas XI IPA 2) pada hari Senin, 10 Februari 2020 pukul 09.45 WITA di ruang kepala madrasah).

${ }^{32}$ Hasil wawancara dengan Andi Husnawati, S.Pd., M.Si.. pada hari Senin, 10 Februari 2020 pukul 10.05 WITA di ruang kepala madrasah).

${ }^{33}$ Hasil wawancara dengan Sarmila Dewi pada hari Senin, 10 Februari 2020 pukul 10.30 WITA di ruang kepala madrasah).
} 


\section{E. SIMPULAN}

Berdasarkan penelitian yang dilakukan oleh peneliti mengenai Pembelajaran Sejarah Kebudayaan Islam Berbasis Gender di Madrasah Aliyah Kabupaten Kepulauan Selayar, maka peneliti dapat menyimpulkan bahwa:

1. Pelaksanaan pembelajaran SKI berbasis gender di Madrasah Aliyah Kabupaten Kepulauan Selayar menggunakan kurikulum 2013. Guru mengajar menggunakan metode yang bervariasi, seperti metode ceramah, tanya jawab, dan yang lainnya. Seluruh peserta didik kelas XI yang terbagi dalam 4 kelas, diampu oleh guru SKI bernama Nur Aida.

2. Faktor yang mendukung dalam proses belajar SKI berbasis gender di Madrasah Aliyah Kabupaten Kepulauan Selayar yaitu diantaranya guru menggunakan metode yang menarik ketika mengajar, sehingga suasana kelas menjadi hidup dan peserta didik sangat bersemangat. Faktor penghambat pembelajaran sejarah kebudayaan Islam berbasis gender di Madrasah Aliyah Kabupaten Kepulauan Selayar yaitu peserta didik belum mengetahui makna gender yang sesungguhnya. Salah satu alasannya adalah, mereka kurang membaca referensi yang berkaitan dengan gender. Hal ini disebabkan kurangnya minat peserta didik membaca materi tentang gender. Selain itu, kesibukan lain berupa tugas dari guru mata pelajaran yang menjadi penyebab perserta didik enggan membaca materi gender. Faktor masa bodoh atau rasa tidak ingin tahu juga menjadi penyebab utama ketidaktahuan mereka tentang materi SKI berbasis gender.

3. Dari semua jenis kesulitan belajar SKI berbasis gender di Madrasah Aliyah Kabupaten Kepulauan Selayar yang dialami oleh peserta didik dan faktor-faktor yang mempengaruhinya, maka pihak sekolah terutama guru mata pelajaran SKI berupaya untuk mengatasi masalah kesulitan belajar SKI berbasis gender. Upaya guru SKI dalam mengatasi kesulitan belajar belajar SKI berbasis gender yang dialami oleh peserta didik yaitu guru mengarahkan lebih awal untuk mencari materi di google yakni materi pembelajaran SKI berbasis gender sehingga peserta didik lebih mudah memahami apa yang diajarkan. Selain itu, buku paket yang sudah tersedia diwajibkan bagi peserta didik untuk membaca lebih awal.

\section{DAFTAR PUSTAKA}

Abd al-Malik bin Hisham, Abu Muhammad. Sïrah al-Nabawiyah. Terj. Fadhli Bahri. Jakarta: Darul Falah, 2000.

Ali Audah, Rasulullah dan Khulafaurrasyidin. Cet. III; Jakarta: Pustaka Litera Antar Nusa, 2011. 
Dewi, Ernita. Jurnal. Kesetaraan Gender dalam Islam: Sudut Pandang Al-Qur'an dan Hadis. Substantia 16, No. 2 Tahun 2014.

Dharma Pendidikan, Profesionalisme Guru dan Paradigma Baru. http://www.blogspot.com/ 20200113/html (13 Januari 2020).

Fitrianti, Rahmi dan Habibullah. Jurnal Penelitian dan Pengembangan Kehidupan Sosial. Ketidaksetaraan Gender dalam Pendidikan. Sosiokonsepsia, 2012.

Hamid, Abd. Rahman dan Muhammad Saleh Majid, Pengantar Ilmu Sejarah. Yogyakarta: Ombak, 2014.

Haekal, Muhammad Husain, Hayat Muhammad. Mesir: Maktabah al Mishriyah, 1968.

Hassan. Ibrahim Hassan, Sejarah dan Kebudayaan Islam. Yogyakarta: Kota Kembang, 1989.

Hidayat, Rakhmat. Jurnal. Bias Gender dalam Prestasi Akademik Siswa: Studi tentang Perbandingan Prestasi Akademik Siswa Laki-laki dan Perempuan di SMA 12 Bekasi. 2011.

Hikmat, Asep dalam Abu A'la al Maududi, Hukum dan Konstitusi Sistem Politik Islam. Cet. IV; Bandung, 1995.

Hilary M. Lips. Sex \& Gender; An Introduction. Californnia: MyField Publishing Company, 1993. Lihat juga Amiruddin Arani dan Faqihuddin Abdul Qadir (ed), dalam Bunga Rampai Tubuh, Seksualitas dan Kedaluatan Perempuan. Yogyakarta: LKis, 2002.

Istibsyaroh, Hak-hak Perempuan Relasi Gender Menurut Tafsir al-Sya'roni, Jakarta: Teraju, 2004.

Jalal al Din al Suyuthi. Tarikh al Khulafa. Beirut: Dar al Fikr, tth.

Jurnal Pendidikan Islam. Gender dan Pengembangan Pemikiran Pendidikan Islam. Volume III Tahun 2014.

K., Ali, Sejarah dan Kebudayaan Islam. Semarang: Toha Karya, 1996.

Lukman, Cecep dalam Philip K. Hitti. History of the Arabs. Cet. I; Jakarta: Serambi Ilmu Semesta, 2002.

Mansour Fakih. Analisis Gender dan Transformasi Sosial. Cet. IV; Yogyakarta: Pustaka Pelajar, 1999.

Mardliyah. Jurnal. Isu Gender Dalam Pendidikan Islam. Jurnal Pendidikan Ilmu Sosial Volume II Tahun 2016.

Miskahuddin. Jurnal. Pengaruh Sosialisasi Gender terhadap Pembentukan Pola Pikir Perempuan Aceh (Studi Kasus di Banda Aceh dan Aceh Besar) Miskahuddin 
Fakultas Ushuluddin dan Filsafat Universitas Islam Negeri (UIN) Ar-Raniry. Volume I No. 2 Tahun 2014.

Mubarok, Jaih, Sejarah Kebudayaan Islam. Bandung: Raja Grafindo Persada, 2004.

Mulia, Siti Musdah, Muslimah Sejati; Menempuh Jalan Islami Meraih Ridha Ilahi, Bandung: Marja, 2011.

Mursidah. Pendidikan Berbasis Kesetaraan dan Keadilan Gender. Volume V No. 2 Tahun 2013.

Priyo Soemandoyo. Wacana Gender \& Layar Televisi: Studi Perempuan Dalam Pemberitaan Televisi Swasta. Yogyakrta: LP3Y, 1999.

Ratna Saptari, Perempuan Kerja dan Perubahan Sosial; Sebuah Pengantar Studi Perempuan, Jakarta: Kalyana Mitra, 1997.

Republik Indonesia, Undang-undang Republik Indonesia Nomor: 20 Tahun 2003 Tentang Sistem Pendidikan Nasional. Cet. IV; Jakarta: Sinar Grafika, 2007.

Setiawan, Arif. Islam di Masa Umar bin Khatthab. Jakarta: Hijri Pustaka, 2002.

Sukmadinata. Metode Penelitian Pendidikan. Cet. I; Bandung: Rosdakarya, 2006.

Sjadzali, Munawir. Islam dan Tata Negara; Ajaran, Sejarah dan Pemikiran. Jakarta: UIPress, 1993.

S K. Kochhar, Pembelajaran Sejarah Teaching of History. Jakarta: Grasindo, 2008. 